\title{
KOMPETENSI GURU PENDAMPING PAUD DALAM MEMENUHI STANDAR LAYANAN PAUD NON FORMAL DI KABUPATEN TASIKMALAYA
}

\author{
Aip Saripudin \\ Institut Agama Islam Negeri Syekh Nurjati Cirebon \\ E-mail: aips@syekhnurjati.ac.id \\ Orcid Id: http://orcid.org/0000-0003-1815-9274
}

Article received: 29 Juli 2019, Review process: 01 Agustus 2019

Article published: 30 September 2019

\begin{abstract}
Teachers should have gained the target of high quality are four competencies will be (1) competence of the personality (2) professional competency (3) competence of pedagogik and (4) social competence. Many strategys has been done by the government in order to realize the teachers of high quality of early childhood education, it which is through provide guidance on the formulation of teachers and education staff of early childhood education. This study used a qualitative methodology that was served a sort of descriptive set explorative. The place of the study is Kecamatan Cikatomas District Tasikmalaya.The technique of data collection through interviews, review of documentation, focus group discussions and questionnaires. The technique of processing data was undertaken through data collection, the reduction of the data, data presentation used to, and the withdrawal of a conclusion. Analysis techniques data using content analysis. The results of the study paper work showing that some aspects in the competence of a pedagogue is still classified as low, and it is requisite to the existence of the form of a strengthening it should also be noted a method of out of school in droves. The aspect of professional competency is still classified as low, can be seen from several aspects of the results of the review of documentation, interview and other of any economic indicators that is indicative of the teacher had not yet over matter of learning of early childhood education paud. Social competence also is still classified as low, can be seen from a number of aspects that is even social program has never been undertaken. This becomes an important issue attention and support the government in to increase the capacity of educator of early childhood education paud that is in kabupaten tasikmalaya especially for the institution of early childhood education paud non formal.
\end{abstract}

Keyword: Competensi, pedagogy, professional, social, PAUD Standar

\begin{abstract}
Abstrak
Guru berkualitas harus memiliki empat kompetensi yakni (1) Kompetensi Kepribadian (2) Kompetensi Profesional (3) Kompetensi Pedagogik dan (4) Kompetensi Sosial. Berbagai strategi telah dilakukan oleh pemerintah untuk mewujudkan guru PAUD yang berkualitas yakni melalui pembinaan pendidik dan tenaga kependidikan PAUD. Penelitian ini
\end{abstract}


menggunakan metode kualitatif yang disajikan secara deskriptif eksploratif. Tempat penelitian yakni lembaga PAUD non formal yang berada di Kecamatan Cikatomas Kabupaten Tasikmalaya. Teknik pengumpulan data melalui wawancara, telaah dokumen, focus group discussion (FGD) dan kuesioner. Teknik pengolahan data dilakukan melalui pengumpulan data, reduksi data, penyajian data, dan penarikan kesimpulan. Teknik analisis data menggunakan teknik analisis isi (Contents Analisys) dan diperkuat dengan teknik prosentase. Hasil penelitian menunjukan bahwa beberapa aspek dalam kompetensi pedagogi masih tergolong rendah, sehingga perlu adanya penguatan secara metode dalam pembelajaran. Aspek kompetensi profesional masih tergolong rendah, terlihat dari beberapa aspek hasil telaah dokumen, wawancara serta angket yang menunjukan guru belum menguasai materi pembelajaran PAUD. Kompetensi sosial juga masih tergolong rendah, terlihat dari beberapa aspek sosial yang bahkan belum pernah dilakukan. Hal ini perlu perhatian dan dukungan pemerintah dalam meningkatkan kapasitas pendidik PAUD yang ada di kabupaten Tasikmalaya khususnya bagi lembaga PAUD non formal.

Kata kunci: Kompetensi, pedagogi, professional, sosial, standar layanan PAUD

\section{PENDAHULUAN}

Anak usia dini didefinisikan oleh the National Association for the Education of Young Children (NAEYC) adalah anak yang berusia 0 sampai 8 tahun (Christianti, 2012). Sedangkan menurut UU No. 20 Tahun 2003 mengatakan bahwa anak usia dini adalah anak yang berusia 0 sampai dengan 6 tahun. Berdasarkan Undang-Undang tersebut, anak usia dini dibina dalam jalur pendidikan formal, nonformal dan informal (Direktorat PAUD). Jalur formal berbentuk Taman Kanak-kanak (TK)/Raudhatul Atfal (RA) dan bentuk lain yang sederajat. Sedangkan jalur pendidikan non formal berbentuk Taman Penitipan Anak (TPA) dan bentuk lain yang sederajat; Kelompok Bermain (KB) dan bentuk lain yang sederajat; Satuan P AUD Sejenis (SPS). Jalur informal adalah pendidikan yang diberikan orang tua dan masyarakat baik secara langsung atau tidak langsung kepada anak (Undang-Undang Republik Indonesia Nomor 20 Tahun 2003 Tentang Sistem Pendidikan Nasional, 2003).

Tertuang dalam rencana strategis kementerian pendidikan dan kebudayaan tahun 2015 bahwa Pendidikan Anak Usia Dini (PAUD) telah menjadi salah satu prioritas program utama pembangunan pendidikan yang dicanangkan dalam Rencana Pembangunan Jangka menengah tahun 2015-2019. Pendidikan anak usia dini merupakan masa-masa emas perkembangan anak. Berbagai studi menunjukkan bahwa periode 5 (lima) tahun pertama kehidupan anak merupakan 'Masa emas' (golden period) atau 'Jendela Kesempatan' (window opportunity) 
AWLADY: Jurnal Pendidikan Anak

Homepage: www.syekhnurjati.ac.id/jurnal/index.php/awlady

Email : pgrasyekhnurjati@gmail.com

P-ISSN: 2541-4658

E-ISSN: 2528-7427
Vol. 5, No. 2, September 2019

dalam meletakkan dasar-dasar tumbuh kembang anak. Kualitas tumbuh kembang anak akan menentukan kualitas nilai moral dan agama, kemampuan kognitif, kemampuan berbahasa, kesehatan fisik dan mental, kemampuan sosial emosional, serta kreatifitas di sepanjang hidupnya. Hal tersebut tidak terlepas dari upaya guru PAUD dalam memberikan layanan pendidikan kepada setiap peserta didiknya. Sehingga guru PAUD diharapkan memiliki kompetensi yang baik dan sesui dengan standar kelayakan minimum sebagi seorang pendidik.

Kompetensi guru PAUD dapat diartikan sebagai kemampuan untuk menguasai keahlian tertentu, sehingga dapat memberikan dampak dalam pengembangan anak usia dini. Kompetensii juga dapat diartikan sebagai bentuk pertanggungjawaban guru kepada stakeholder dalam rangka melaporkan kegiatan pembelajaran pada anak usia dini. Kompetensi diartikan sebagai pengetahuan, keterampilan, dan nilai-nilai dasar yang direfleksikan dalam kebiasaan berpikir dan bertindak. Arti lain dari kompetensi adalah spesifikasi dari pengetahuan, keterampilan, dan sikap yang dimiliki seseorang serta penerapannya di dalam pekerjaan, sesuai dengan stndar kinerja yang dibutuhkan oleh lapangan (Sutarmanto, 2015). Adapun kompetensi Guru PAUD mencakup kompetensi pedagogik, kepribadian, sosial, dan professional (Kementerian Pendidikan dan Kebudayaan, 2014).

Kompetensi pedagogik bagi guru PAUD merupakan kemampuan guru dalam menguasai metode pembelajaran. Penguasaan materi bidang studi merupakan kompetensi pertama yang harus dimiliki guru PAUD sebagai dasar untuk melaksanakan program pembelajaran yang lebih bermakna (Pitrawati, Fadillah, 2016). Hasil penelitian terdahulu telah mengidentifikasi indikator-indikator yang terkait dengan kompetensi pedagogik yakni menangani permasalahan anak di dalam kelas, mengidentifikasi minat dan kebutuhan anak, mengidentifikasi ciri-ciri kepribadian anak, mengidentifikasi gaya belajar anak, mengenal dan memanfaatkan lingkungan, memahami kegiatan pembelajaran anak usia dini, menciptakan strategi yang tepat dalam merancang kegiatan belajar yang menyenangkan, memfasilitasi anak didik untuk mengembangkan potensi di bidang akademik, Memfasilitasi anak didik untuk mengembangkan potensi di bidang nonakademik Pendekatan (Mustika, 2015).

Kompetensi kepribadian merupakan kemampuan seorang guru PAUD dalam mengelola dirinya sendiri. Kompetensi kepribadian terkait dengan sikap dan tingkah laku guru dalam kesehariannya, sehingga menjadi bagian yang dapat ditiru oleh siswa dan 
AWLADY: Jurnal Pendidikan Anak

Homepage: www.syekhnurjati.ac.id/jurnal/index.php/awlady

Email : pgrasyekhnurjati@gmail.com

P-ISSN: 2541-4658

E-ISSN: 2528-7427
Vol. 5, No. 2, September 2019

lingkungan sekitarnya. Sedangkan indikator kompetensi kepribadian mencakup Bertindak sesuai dengan norma agama, hukum, sosial, dan kebudayaan nasional Indoensia, Menampilkan diri sebagai pribadi yang jujur, berakhlak mulia, dan teladan bagi peserta didik dan masyarakat, Menampilkan diri sebagai pribadi yang mantap, stabil, dewasa, arif, dan berwibawa, Menunjukkan etos kerja, tanggung jawab yang tinggi, rasa`bangga menjadi guru, dan rasa percaya diri, serta menjunjung tinggi kode etik profesi guru (Sutarmanto, 2015).

Kompetensi Sosial yang dimiliki guru PAUD tercermin dalam sikap yang ditunjukan kepada siswa dan masyarakat atau lingkungan temppat bekerja terkait dengan interaksi antara guru dengan siswa, guru dengan guru serta guru dengan orang tua. Slameto dalam jurnal mengemukakan bahwa kompetensi sosial berkaitan dengan kemampuan pendidik sebagai bagian dari masyarakat untuk berkomunikasi secara efektif dengan peserta didik, sesama pendidik, tenaga kependidikan, orang tua peserta didik, dan masyarakat sekitar (Afandi, 2015)

Kompetensi Profesional terkait dengan kemampuan guru dalam menguasai materi pembelajaran. Dalam hal ini guru PAUD dituntut untuk menguasai materi pembelajaran untuk anak usia dini sesuai dengan tahapan pekrmebangan anak. Dalam menunjukan kemampuan guru terkait dengan kompetensi professional, maka guru selayaknya mengetahui tahapantahapan perkembangan anak, serta memiliki kesiapan dalam memberikan materi sesuai dengan standar yang telah ditetapkan. Hasil penelitian yang dipublikasikan oleh jurnal Pendidikan dan Pembelajaran Tanjung Pura menemukan indikator kompetensi professional tercermin dalam Menguasai Materi Pembelajaran Anak Usia Dini, Menguasai Standar Kompetensi dan Kompetensi Dasar Mata Pelajaran Anak Usia Dini, Mengembangkan Materi Pembelajaran Anak Usia Dini Secara Kreatif, Mengembangkan Keprofesionalan dengan Melakukan Tindakan Reflektif dalam Pembelajaran Anak Usia Dini, serta Memanfaatkan Teknologi Informasi dan Komunikasi untuk Berkomunikasi dan Mengembangkan Diri (Pitrawati, Fadillah, 2016).

Program peningkatan mutu pendidik PAUD telah diberlakukan selama ini melalui kegiatan Kelompok Kerja Guru Taman Kanak-kanak (KKGTK) pada Gugus Taman Kanakkanak (TK). Selain itu penguatan materi pembelajaran PAUD serta kompetensi dasar lainnya yang harus dimiliki oleh pendidik PAUD telah dilakukan oleh gugus PAUD yang ada di berbagai wilayah dari tingkat kecamatan hingga tingkat Kabupaten. Namun sampai sejauh ini 
AWLADY: Jurnal Pendidikan Anak

Homepage: www.syekhnurjati.ac.id/jurnal/index.php/awlady

Email : pgrasyekhnurjati@gmail.com

P-ISSN: 2541-4658

E-ISSN: 2528-7427
Vol. 5, No. 2, September 2019

masih juga belum menapakan hasil yang maksimal. Terbukti masih banyak guru-guru PAUD yang belum memiliki kecakapan pedagogik dan kecakapan professional yang mumpuni. Fakta lapangan menunjukan bahwa ada guru PAUD yang masih menggunakan metode ceramah dalam kegiatan pembelajaran di PAUD. Selain itu masih banyaknya pendidik PAUD yang menargetkan calistung dalam pembelajaran PAUD dan melupakan aspek perkembangan lainnya. Hal ini tentunya menjadi kendala dalam meningkatkan mutu pembelajaran PAUD terlebih lagi mengabaikan pembelajaran anak sesuai dengan tahapan perkembangannya. Saat ini perkembangan layanan melalui lembaga PAUD telah banyak kita jumpai di berbagai wilayah di tanah air. Berbagai bentuk layanan PAUD seperti TK, RA, Taman Penitipan Anak (TPA), Kelompok Bermain (KB), dan Satuan PAUD Sejenis (SPS) semakin banyak. Hal ini menunjukkan bahwa semakin meningkatnya kesadaran masyarakat tentang pentingnya pendidikan yang sesuai dengan tahapan perkembangan anak usia dini. Peningkatan minat masyarakat tersebut diikuti dengan meningkatnya kebutuhan tanga pendidik (Guru TK/PAUD) yang berkualitas.

Berbagai startegi dilakukan pemerintah untuk mewujudkan guru TK/PAUD yang berkualitas diantaranya ditempuh oleh Direktorat Jenderal Pendidikan Nasional Anak Usia Dini Non Formal dan Informal yaitu melalui pembianan pendidik dan tenaga kependidikan PAUD yang dilakukan melalui Gugus PAUD. Berdasarkan studi pendahuluan yang dilakukan peneliti di lapangan ditemukan bahwa minat masyarakat terhadap PAUD terus meningkat dari tahun ke tahun. Permasalahan pendidikan yang kita hadapi saat ini adalah kualitas pendidikan yang harus dilakukan melalui upaya peningkatan kualitas guru pendamping. Namun kenyataan menunjukkan bahwa kualitas guru PAUD di Kabupaten Tasikmalaya masih beragam. Hal ini antara lain disebabkan oleh tidak terpenuhinya kualitas pendidikan minimal S1 bagi Guru PAUD. Berdasarkan data Januari 2016, jumlah lembaga PAUD mencapai 190.238 lembaga. Sementara guru PAUD di Indonesia mencapai 750.769 orang terdiri dari 31.721 orang lulusan SMP, 366.818 lulusan SMA, 238.003 oang lulusan sarjana (S1/D4) dan 5671 orang merupakan tenaga ahli dan merupakan lulusan pascasarjana (Sapulidi research centre, 2016). Sementara jumlah guru PAUD di Kabupaten Tasikmalaya sebanyak 3600 orang guru. Berdasarkan data tersebut maka dapat dilihat bahwa jumlah guru PAUD lulusan SMP dan SMA lebih banyak dibandingkan dengan jumlah lulusan sarjana. Selain itu, salah 
AWLADY: Jurnal Pendidikan Anak

Homepage: www.syekhnurjati.ac.id/jurnal/index.php/awlady

Email : pgrasyekhnurjati@gmail.com

P-ISSN: 2541-4658

E-ISSN: 2528-7427
Vol. 5, No. 2, September 2019

68

satu permasalahan kompetensi guru PAUD yang terjadi di Kabupaten Tasikmalaya saat ini adalah kondisi keuangan yang tidak memungkinkan para guru PAUD untuk melanjutkan studi keperguruan tinggi. Pada aspek pembelajaran, mereka tidak membiasakan melakuakan refleksi pembelajaran melalui penelitian tindakan kelas untuk meningkatkan strategi dan metode pembelajaran yang lebih baik.

\section{METODOLOGI}

Penelitian ini menggunakan rancangan kualitatif yang disajikan secara deskriptif eksploratif dengan jenis penelitian studi kasus. Penelitian ini mengeksplorasi suatu masalah dengan cara pengambilan data yang mendalam dan menyertakan berbagai sumber informasi. Penelitian ini telah diaksanakan selama 4 bulan. Tempat penelitian yakni lembaga PAUD non formal yang berada di kabupaten Tasikmalaya. Pengumpulan data primer dalam penelitian ini dilakukan melalui wawancara mendalam agar dapat menggali lebih banyak informasi dari para informan. Key informan dalam penelitian ini adalah guru-guru pendamping yang merupakan informan utama. Untuk triangulasi, wawancara juga dilakukan kepada kepala sekolah, ketua yayasan serta pengawas sekolah. Untuk memperkuat analisis data hasil penelitian, maka peneliti juga melakukan penyebaran angket kepada guru-guru pendamping PAUD yang berada di Kabupaten Tasikmalaya. Adapun teknik pengumpulan data dalam penelitian ini yakni (1) wawancara kepada semua informan kunci untuk memperoleh informasi terkait dengan kompetensi guru (2) Telaah dokumen, yakni mengkaji/menelaah dokumen-dokumen administrative guru pendamping serta dokumen dokumen pembelajaran peserta didik yang diambil secara langsung melalui kegiatan observasi pembelajaran. (4) Focus group discussion (FGD) dilakukan kepada perwakilan guru dan kepala sekolah dari masing-masing lembaga. (5) Kuesioner, diberikan kepada guru pendamping PAUD melalui angket tertutup. Pengolahan data dalam penelitian ini menggunakan tahapan pengolahan data deskriptif kualitatif yang terdiri dari tahapan pengumpulan data, reduksi data, penyajian data, dan penarikan kesimpulan. Penyajian data dilakukan dengan menyajikan data-data deskriptif maupun data-data kuantitatif dalam bentuk bagan atau chart. Penarikan kesimpulan dilakukan ketika data-data sudah selesai dianalisis dan siap untuk disimpulkan sesuai dengan tujuan penelitian yang diharapkan. Analisis data dalam penelitian ini dilakukan pada saat pengumpulan data berlangsung dan setelah selesai pengumpulan data. Teknik yang digunakan 
AWLADY: Jurnal Pendidikan Anak

Homepage: www.syekhnurjati.ac.id/jurnal/index.php/awlady

Email : pgrasyekhnurjati@gmail.com

P-ISSN: 2541-4658

E-ISSN: 2528-7427
Vol. 5, No. 2, September 2019

69

dalam menganalisis data yang diperoleh melalui wawacara mendalam yakni menggunakan teknik analisis isi (Contents Analisys). Sementara analisis data yang diperoleh melalui kuesioner yakni dengan menggunakan analisis prosentase.

\section{HASIL DAN PEMBAHASAN}

Penelitian ini dilakukan atas dasar peraturan menteri pendidikan nasional nomor 137 tahun 2014 tentang standar nasional pendidikan anak usia dini. Pada BAB IV pasal 25 ayat 2 dikatakan bahwa Kompetensi Guru PAUD dikembangkan secara utuh mencakup kompetensi pedagogik, kepribadian, sosial, dan profesional, sebagaimana terdapat pada lampiran II yang merupakan bagian tidak terpisahkan dari Peraturan Menteri ini (Kementerian Pendidikan dan Kebudayaan, 2014).

Guru PAUD seyogianya memiliki 4 kompetensi seperti yang telah diatur dalam undang-undang. Guru yang memiliki kompetensi atau kecakapan dalam pembelajaran, maka mereka akan dikatakan sebagai guru professional. Hal ini dikatakam oleh Driscoll, Amy dan Nagel, Nancy G bahwa "a profesional is someone who is educa- ted, knowledgeable, dedicated to her profession, committed to completion of a specialized course of study, and in possesion of a knowladge base essential to her specialty area" (Christianti, 2012). Pernyataan tersebut menunjukan bahwa bahwa guru yang memiliki kompetensi, memiliki komitmen, memiliki pengetahuan serta mendedikasikan dirinya maka dapat dikatakan sebagai guru yang professional. Untuk mengetahui fakta lapangan tentang guru PAUD di Kabupaten Tasikmalaya, khususnya di Kecamatan Cikatomas, maka kita memulai dari aspek akademik, aspek pedagogic serta, aspek social serta aspek professional.

\section{Analisis Kompetensi Pedagogi Pendidik PAUD Non Formal}

Salah satu kompetensi yang harus dimiliki guru PAUD non formal yakni kompetensi pedagogi. Kompetensi pedagogi terkait dengan bagaimana guru dapat mengelola peserta didik. Pengelolaan peserta didik termasuk didalamnya bagaimana mengelola lingkungan belajar, pengelolaan pembelajaran kelas, serta hubungannya dengan pemberian rangsangan kepada peserta didik. Hasil penelitian terdahulu menunjukan bahwa dengan melakukan pendekatan secara individual dan juga menjadikan biodata peserta didik sebagai referensi maka hubungan guru dengan murid akan semakin akrab (Novauli, 2012). 
AWLADY: Jurnal Pendidikan Anak

Homepage: www.syekhnurjati.ac.id/jurnal/index.php/awlady

Email : pgrasyekhnurjati@gmail.com

P-ISSN: 2541-4658

E-ISSN: 2528-7427

Hasil penelitian yang dilakukan di kecamatan Cikatomas terkait kompetensi pedagogi guru pendamping PAUD, maka dalam aspek tujuan pembelajaran guru pendamping PAUD telah menyempaikan tujuan pembelajaran setiap hari kepada peserta didik. Begitupula dengan pemberian motivasi, melakukan penilaian kepada peserta didik, melakukan apersepsi setiap pertemuan, melakukan recolling, serta menggunakan media pembelajaran dalam setiap pertemuan selalu dilakukan oleh guru. Prosentase jawaban selalu melakukan kegiatan sesuai dengan indikator kompetensi pedagogi yakni diatas 50\%. Sementara yang terkait dengan menciptakan kreatifitas, merangsang anak untuk berkelompok dan bekerjasama, memberikan tugas tugas tambahan di rumah, mengenalkan lingkungan alam, serta mengelola pembelajaran aktif dalam kelas sering dilakukan namun jawaban guru dibawah 50\%. Secara umum kompetensi pedagogik guru pendamping PAUD non formal dapat dilihat dalam gambar dibawah ini:

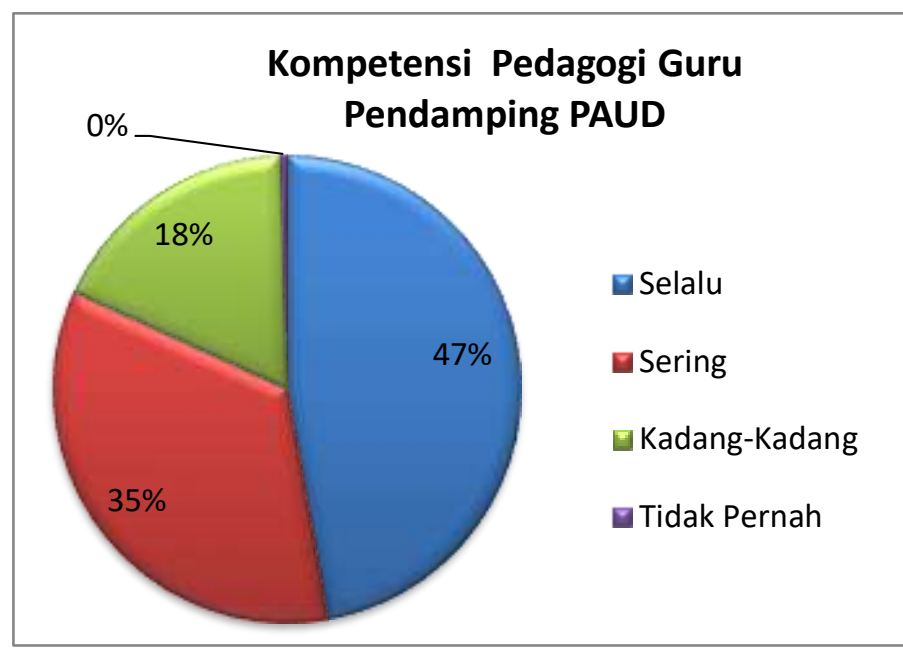

Gambar disamping menunjukan bahwa terdapat aspek-aspek lain dalam kompetensi pedagogi yang masih terbatas dikuasai oleh guru pendamping PAUD. Hasil wawancara dengan kepala sekolah salah satu PAUD non formal mengatakan adanya keterbatasan guru dalam penguasaan keterampilan manajemen pembelajaran di PAUD, sehingga memunculkan pembelajaran yang apa adanya. Aspek melakukan penilaian, menciptakan suasana pembelajaran aktif falam kelas, mengenalkan lingkungan alam, melakukan apersepsi dalam setiap pertemuan, melakukan recolling serta penggunaan media pembelajaran menunjukan hasil yang kadang-kadang dilakukan oleh guru, padahal aspek-aspek tersebut mutlah harus selalu dilakukan oleh guru PAUD dalam setiap pembelajaran. Tidak dikatakan pembelajaran jika tidak terjadi interaksi antar guru dengan siswa. Interaksi disini merupakan proses aktif yang dilakukan oleh guru dan yang dilakukan oleh siswa secara bersama sama tanpa dominasi oleh salah satu pihak. Menurut Saifurrahman Pelaksanaan pembelajaran adalah cara guru dalam mengimplementasikan 
materi dalam pembelajaran misalnya mengajukan pertanyaan, menyajikan gambar-gambar, memperagakan, merasakan, mengamati, dan melibatkan siswa untuk berpartisipasi aktif selama proses pembelajaran berlangsung (Yusniar, 2015).

Hasil wawancara dengan salah satu guru PAUD non formal mengatakan bahwa anak jarang diperkenlkan dengan lingkungan alam seperti mengenal tumbuhan, hewan dan lingkungan sekitar (Wawancara Tgl 9 September 2018). Menurut pengamatan peneliti lembaga PAUD yang berlokasi di Kecamatan Cikatomas sangat kaya dengan lingkung alam, sehingga sangat mudah mengembangkan kecerdasan Naturalis kepada peserta didik. Thomas Armstrong mengemukakan bahwa kecerdasan naturalistik adalah:"expertise in the recognition and classification of the numerios species-the flora and fauna-of an individual's environment. This also includes sensitivity to other natural phenomena (e.g.,cloud formation, mountains, etc) and, in the case of thouse growing up in an urban environment, the capacity to discriminate among inanimate objects such as cars, snearkes, and CD covers (Saripudin, 2017). Artinya menemukan binatang peliharaan, menemukan tumbuhan, menemukan hewan yang berada di lembaga PAUD yang notabene berada di perkampungan sangat mudah. Respon guru sebesar $28.57 \%$ yang mengatakan jarang memperkenalkan alam kepada anak itu sesuatu hal yang diluar dugaan. Hal ini tidak dilakukan semata-mata karena faktor pengetahuan guru dalam memahami konteks pembelajaran di PAUD yang masih terbatas.

\section{Analisis Kompetensi Profesional Pendidik PAUD Non Formal}

Kompetensi professional guru PAUD terkait dengan kemampuan guru dalam menguasai materi pembelajaran di PAUD. Muatan-muatan kurikulum dalam kurikulum 2013 PAUD mutlak harus dikuasai oleh guru PAUD. Muatan kurikulum Pendidikan Anak Usia Dini berisi program-program pengembangan yang terdiri dari: (1) Program pengembangan nilai agama dan moral mencakup perwujudan suasana belajar untuk berkembangnya perilaku baik yang bersumber dari nilai agama dan moral serta bersumber dari kehidupan bermasyarakat dalam konteks bermain. (2) Program pengembangan fisik-motorik mencakup perwujudan suasana untuk berkembangnya kematangan kinestetik dalam konteks bermain. (3) Program pengembangan kognitif mencakup perwujudan suasana untuk berkembangnya kematangan proses berpikir dalam konteks bermain. (4) Program pengembangan bahasa mencakup perwujudan suasana untuk berkembangnya kematangan bahasa dalam konteks 
AWLADY: Jurnal Pendidikan Anak

Homepage: www.syekhnurjati.ac.id/jurnal/index.php/awlady

Email : pgrasyekhnurjati@gmail.com

P-ISSN: 2541-4658

E-ISSN: 2528-7427

bermain. (5) Program pengembangan sosial-emosional mencakup perwujudan suasana untuk berkembangnya kepekaan, sikap, dan keterampilan sosial serta kematangan emosi dalam konteks bermain. (6) Program pengembangan seni mencakup perwujudan suasana untuk berkembangnya eksplorasi, ekspresi, dan apresiasi seni dalam konteks bermain (Peraturan Menteri Pendidikan dan Kebudayaan Republik Indonesia Nomor 146 Tahun 2014 Tentang Kurikulum 2013 Pendidikan Anak Usia Dini, 2014)

Hasil penelitian lapangan bahwa kompetensi professional guru pendamping PAUD non formal di Kecamatan Cikatomas Kabupaten tasikmalaya dilihat dari aspek penguasaan konsep perkembangan anak, penguasaan kebijakan-kebijakan PAUD, pembelajaran tematik pada pembelajaran anak usia dini, penggunaan pendekatan saintifik dalam pembelajaran, pendekatan bermain dalam setiap pembelajaran, penggunaan media sesuai tahapan perkembangan anak serta pembelajaran berdasarkan kurikulum 2013 PAUD menunjukan hasil secara umum baik. Namun sebesar 1,43\% guru pendamping berkategori buruk terutama dalam penguasaan konsep pendekatan dalam pembelajaran PAUD serta penggunaan pembelajaran tematik yang tidak pernah dilakukan. Untuk melihat gambaran secara umum mengenai kompetensi profesionalisme guru PAUD dapat dilihat dalam grafik dibawah ini:

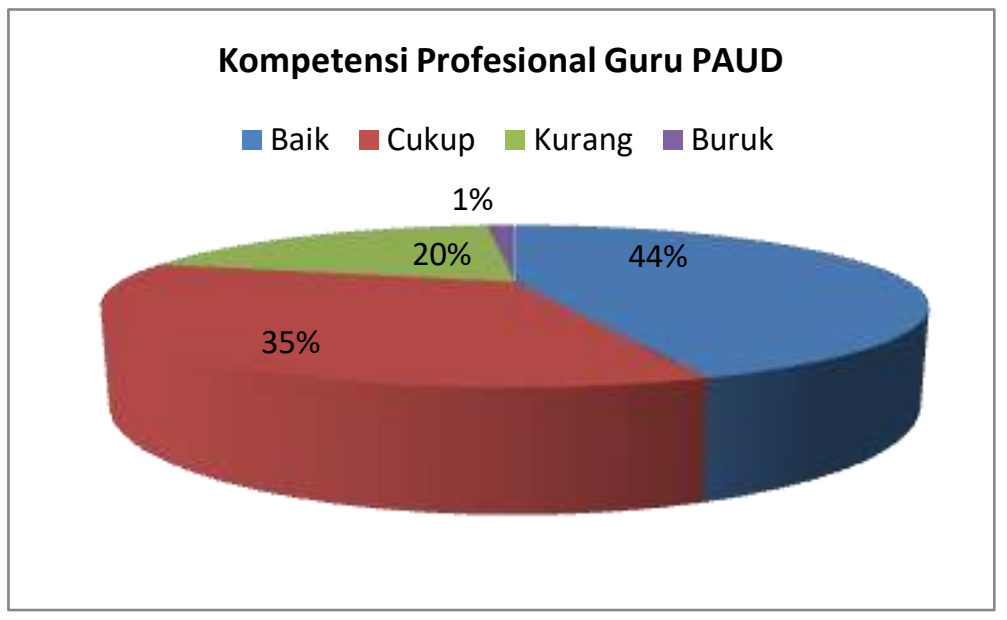

\section{Gambar}

disamping menunjukan bahwa sebesar $44,29 \%$ guru pendamping PAUD berkategori baik dalam hal penguasaan konsep perkembangan AUD, penguasaan konsep dasar AUD, pembelajaran selalu menggunakan pendekatan

bermain, serta pembelajaran berdasarkan kurikulum 2013 PAUD. Dalam hal memperkenalkan calistung untuk anak usia dini, para guru juga telah melakukannya dengan pendekatan bermain. Sehingga calistung tidak lagi diperkenalkan dalam bentuk-bentuk yang membosankan. Kategori kurang baik yakni 19,52\% ditunjukan dalam aspek penguasaan 
AWLADY: Jurnal Pendidikan Anak

Homepage: www.syekhnurjati.ac.id/jurnal/index.php/awlady

Email : pgrasyekhnurjati@gmail.com

P-ISSN: 2541-4658

E-ISSN: 2528-7427
Vol. 5, No. 2, September 2019

73

kebijakan-kebijakan dalam pembelajaran PAUD serta penggunaan pendekatan saintifik dalam pembelajaran PAUD. Guru semetinya mengetahui tentang kebijakan-kebijakan PAUD, sehingga akan memudahkan mereka dalam melakukan pembelajaran sesuai dengan kebijakan yang ada.

Selain itu kebijakan terkait dengan kesejahtaeraan guru PAUD, regulasi yang terkait dengan syarat dan ketentuan menjadi guru PAUD minim diketahui oleh guru PAUD. Senada dengan hasil survey tersebut, hasil wawancara dengan ketua HIMPAUDI mengatakan bahwa guru PAUD cenderung tidak perduli dengan kebijakan-kebijakan yang ada, mereka belum mampu melek dalam hal memahami aturan-aturan khususnya dalam konteks pembelajaran di PAUD (wawancara dengan Ketua HIMPAUDI, 23 Agustus 2018). Dari temuan penelitian tersebut, maka peran aktif pemerintah sangat diperlukan terutama dalam mengatur regulasi, mensosialisasikan regulasi kepada masyarakat hingga mengatur standar umum PAUD baik program maupun penilaian. Yang perlu diatur oleh pemerintah adalah juklak juknis yang berkaitan dengan materi pokok, sedangkan materi lokal atau tambahan diberikan kebebasan bagi setiap lembaga PAUD untuk mengembangkan ide, kreasi, dan kreativitas sesuai ciri khas dan karekteristik setiap lembaga PAUD (Kiam, 2014)

\section{Analisis Kompetensi Sosial Pendidik PAUD Non Formal}

Kompetensi sosial terkait dengan sikap guru dalam berinteraksi baik dengan murid, orangtua bahkan sesame guru di lingkungan tempat dia bekerja. Kompetensi sosial guru PAUD tercermin dalam keseharian guru PAUD dalam berinteraksi dengan orang-orang yang berda di lingkungannya. Secara umum kompetensi sosial guru pendamping PAUD non formal di Kecamatan Cikatomas Kabupaten Tasikmalaya dapat dilihat dalam gambar berikut:

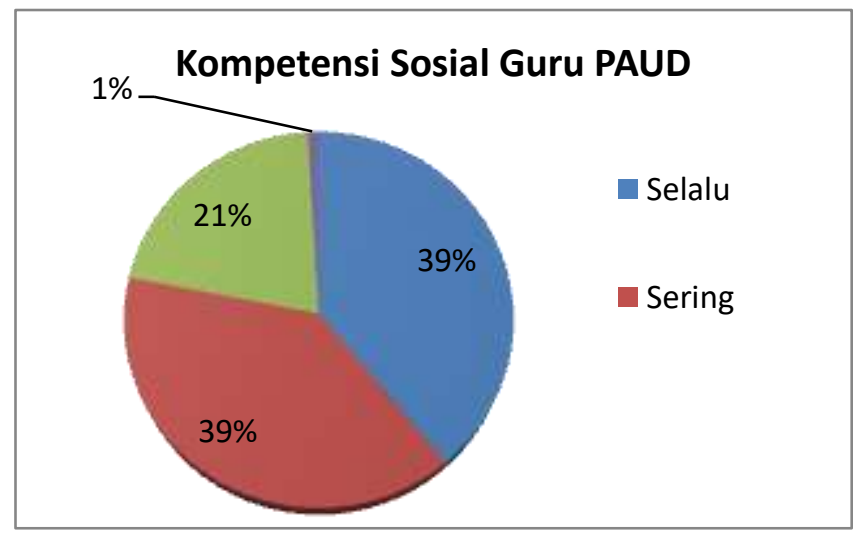

Fokus pada aspek kompetensi sosial guru PAUD terdiri dari aspek cara melakukan komunikasi dengan anak secara santun dan ramah, menjunjung tinggi nilai-nilai sekolah ramah anak, dalam setiap proses pembelajaran bekerjasama dengan anak, 
AWLADY: Jurnal Pendidikan Anak

Homepage: www.syekhnurjati.ac.id/jurnal/index.php/awlady

Email : pgrasyekhnurjati@gmail.com

P-ISSN: 2541-4658

E-ISSN: 2528-7427
Vol. 5, No. 2, September 2019

komunikasi dengan orangtua secara intensif, pemberian pengetahuan tentang nilai nilai yang baik di sekolah baik untuk anak maupun orang tua, komunikasi intensif dengan masyarakat sekitar terkait dukungan terhadap lembaga, keterbilatan tokoh masyarakat dalam lembaga PAUD, serta adanya transparansi penggunaan dana kepada masyarakat. Dari aspek-aspek tersebut diatas, maka 39\% guru selalu melakukan aspek-aspek yang terkait dengan kompetensi sosial guru PAUD serta 39\% sering melakukan aspek-aspek yang terkait dengan kompetensi sosial guru. Namun hal baik yang seharusnya intensif dilakukanyakni keterlibatan tokoh masyarakat serta komunikasi dengan masyarakat sekitar terkait dengan program-program PAUD jarang dilakukan. Padahal ini merupakan kunci sukses dukungan warga terhadap penyelenggaraan program PAUD di tingkat bawah. Hasil wawancara dengan Ibu Ihah Solihah salah satu guru PAUD mengatakan bahwa memang jarang komunikasi dengan masyarakat sekitar, paling dengan orangtua dalam hal kegiatan PAUD. Begitu pula dengan tokoh masyarakat, tokoh masyarakat yang terlibat hanya ketua DKM saja (wawancara dengan guru PAUD tanggal 19 Agustus 2018)

Selanjutnya, dari gambar diatas ternyata masih ada guru PAUD yang tidak pernah melakukan komunikasi dengan orang tua dalam hal penyelenggaraan kegiatan pembelajaran PAUD. Sekitar $1 \%$ mengaku tidak pernah melakukan komunikasi dengan orang tua baik secara formal dalam bentuk rapat orang tua maupun secara informal. Hal ini sulit dipahami karena peran orang tua sangat penting dalam pembelajaran anak. Orang tua perlu mengetahui perkembangan anak, sehingga kerjasama antara orangtua dan guru sangat penting. Penelitian Henderson seperti yang dikutip oleh Soemiarti Padmonodewo dalam Dwi Partiningsih, menunjukkan bahwa prestasi anak akan meningkat apabila para orang tua peduli terhadap anak mereka. Penemuannya yang berkaitan dengan keterlibatan orang tua adalah sebagai berikut: (a) Lingkungan keluarga, bukan lingkungan sekolah, adalah lingkungan belajar anak yang pertama (b) Keterlibatan orangtua dalam pendidikan formal anak akan meningkatkan prestasi sekolah anak (c) Keterlibatan orangtua terhadap sekolah lebih efektif apabila terencana dengan baik dan berjalan dalam jangka panjang (d) Keterlibatan orangtua terhadap pendidikan anak sebaiknya dilakukan sedini mungkin dan berkelanjutan (e) Keterlibatan orangtua terhadap pendidikan anak-anak di rumah, belum cukup. Meningkatkan prestasi anak baru tampak apabila orangtua melibatkan diri di dalam pendidikan anak di sekolah (f) 
Anak-anak yang berasal dari keluarga yang tidak mampu serta minoritas akan menunjukkan peningkatan prestasi apabila orangtua terlibat dalam kegiatan anak, walaupun pendidikan orangtua berbeda sekalipun (Pratiningsih, 2017).

Dalam hal transparansi penggunaan dana lembaga PAUD, ada beberapa lembaga PAUD yang belum melaksanakan prinsip-prinsip transparan dalam penggunaan dana. Alokasi dana yang bersumber dari pemerintah masih bersifat tertutup untuk diakses oleh masyarakat. Beberapa guru PAUD di Kecamatan Cikatomas dalam sesi wawancara mengatakan bahwa tidak mengetahui penggunaan anggaran dana lembaga PAUD. Pengelolaan dana didominasi oleh kepala sekolah serta staf yang dipercaya dalam mengelola keuangan lembaga. Dari hasil observasi lapangan ditemukan ada beberapa guru dan kepala sekolah yang statusnya masih kerabat, sehingga sulit untuk objektif dalam mengelola laporan keuangan. Hasil angket mengatakan bahwa 19,05\% guru kadang-kadang diberitahu tentang penggunaan dana operasional lembaga. Hal ini menunjukan bahwa masih terdapat guru PAUD yang belum sepenuhnya transparan dalam hal keuangan lembaga dan jarang melakukan komunikasi tersebut dengan guru lain apalagi dengan masyarakat sekitar.

\section{SIMPULAN}

Kompetensi guru pendamping PAUD di Kecamatan Cikatomas Kabupaten Tasikmalaya dalam beberapa aspek masih tergolong rendah. Dalam hal menciptakan suasana kerjasama anatar guru dengan anak jarang dilakukan. Selain itu pemberian tugas-tugas tambahan bagi siswa PAUD masih sering dilakukan oleh guru. Tugas-tugas pekerjaan rumah semestinya tidak banyak diterapkan di lembaga PAUD. Namun kenyataannya terdapat $42,86 \%$ guru PAUD yang masih melakukan penugasan berupa pekerjaan rumah kepada anak. Komptensi professional guru PAUD juga masih tergolong rendah dalam beberapa aspek seperti penguasaan konsep-konsep perkembangan anak usia dini, pemahaman kebijakankebijakan PAUD, penguasaan pembelajaran tematik, pendekatan bermain dalam pembelajaran serta pendekatan bermain dalam pembelajaran calistung. Beberapa guru mengatakan konsep calistung diberikan secara langsung kepada anak tanpa menggunakan pendekatan bermain. Sebesar 4,76\% guru PAUD tidak menggunakan pendekatan bermain dalam pembelajaran calistung. Hal ini tentunya bertentangan dengan konsep Development Apropriate Practice yang mengatakan bahwa pembelajaran harus sesuai dengan usia 
AWLADY: Jurnal Pendidikan Anak

Homepage: www.syekhnurjati.ac.id/jurnal/index.php/awlady

Email : pgrasyekhnurjati@gmail.com

P-ISSN: 2541-4658

E-ISSN: 2528-7427
Vol. 5, No. 2, September 2019

perkembangannya dan dikembangkan melalui pendekatan bermain. Dalam beberapa aspek memang kompetensi social guru PAUD sudah memenuhi standar layanan. Namuan masih ada beberapa aspek dalam kompetensi social guru PAUD yang perlu diperhatikan dan perlu banyak pembelajaran. Aspek bekerjasama dengan orangtua mutlak harus diperhatikan. Masih ada beberapa guru yang enggan komunikasi intensif dengan orang tua, sehingga menimbulkan miskomunikasi anatara guru dengan orang tua. Pentingnya komunikasi intensif guru dengan orangtua juga penting dalam mengkomunikasikan perkmebangan anak serta hal-hal baik yang telah diajarkan di sekolah. Kunci sukses dalam meningkatkan kompetensi guru pendamping PAUD yakni adanya keterlibatan dan peran serta pemerintah dalam mensosialisasikan mutu guru PAUD. Pembinaan yang dilakukan dapat berupa kegiatan-kegiatan yang bersifat formal maupun informal. Kerjasama pemerintah dengan berbagai asosiasi pendidik PAUD dari tingkat pusat hingga tingkat kecamatan juga sangat penting, mengingat guru PAUD rata-rata aktif dalam kegiatan-kegiatan gugus PAUD. Sehingga informasi-informasi yang bersifat kebijakan pengembangan dapat tersosialisasikan dengan baik.

\section{UCAPAN TERIMAKASIH}

Penulis secara langsung mengucapkan terimakasih kepada semua pihak yang telah membantu dalam kegiatan penelitian ini. Secara khsus penulis mengucapkkan terimakasih kepada ketua Himpunan Pendidik Anak Usia Dini Indonesia Kecamatan Cikatomas Kabupataen Tasikmalaya Jawa Barat yang telah memberikan banyak kesempatan untuk melakukan penelitian di wilayah tersebut. Kepada para narasumber yakni kepala sekolah dan guru-guru PAUD non formal di Kecamatan Cikatomas yang telah memebrikan informasi secara penuh dalam kaitannya dengan penelitian yang penulis lakukan. Ucapan terimakasih penulis sampaikan kepada IAIN syekh Nurjati Cirebon yang telah memebrikan dukungan berupa dana dan fasilitas dalam kegiatan penelitian ini. Penelitian ini dibiayai oleh DIPA IAIN Syekh Nurjati Cirebon Tahun 2018.

\section{DAFTAR PUSTAKA}

Afandi, M. (2015). Kompetensi Guru Sebagai Kunci Keberhasilan Dalam Pembelajaran Saintifik. In Seminar Nasional Pendidikan (pp. 74-88).

Christianti, M. (2012). Profesionalisme Pendidik Anak Usia Dini. Jurnal Pendidikan Anak, 1(1), 112-122. https://doi.org/10.1007/978-3-642-39241-2_58 
AWLADY: Jurnal Pendidikan Anak

Homepage: www.syekhnurjati.ac.id/jurnal/index.php/awlady

Email : pgrasyekhnurjati@gmail.com

P-ISSN: 2541-4658

E-ISSN: 2528-7427
Vol. 5, No. 2, September 2019

77

Kementerian Pendidikan dan Kebudayaan. Peraturan Menteri Pendidikan dan Kebudayan Nomor 137 Tahun 2014 tentang Standar Nasional Pendidikan Anak Usia Dini (2014).

Kiam. (2014). Implementasi Kebijakan Program Pendidikan Non Formal Pada Pendidikan Anak Usia Dini (PAUD) Di Kecamatan Sintang. Jurnal Administrasi Publik Dan Birokrasi, 1(1).

Mustika. (2015). Kompetensi Pedagogik Guru Taman Kanak-kanak Negeri Pembina di Tarakan. Jurnal Kebijakan Dan Pengembangan Pendidikan, 3(1), 93-98.

Novauli, F. (2012). Pengaruh Kompetensi Guru Terhadap Peningkatan Prestasi Belajar Pada SMP Negeri di Kota Banda Aceh. Jurnal Pencerahan, 6(1), 17-32.

Peraturan Menteri Pendidikan dan Kebudayaan Republik Indonesia Nomor 146 Tahun 2014 Tentang Kurikulum 2013 Pendidikan Anak Usia Dini (2014).

Pitrawati, Fadillah, Y. D. (2016). Analisis Kompetensi Profesional Guru PAUD di Kecamatan Serasan Kabupaten Natuna. Jurnal Pendidikan Dan Pembelajaran Tanjung Pura, 5(2). Retrieved from http://jurnal.untan.ac.id/index.php/jpdpb/artiAcle/viewFile/14984/13245

Pratiningsih, D. (2017). Efektivitas Kerjasama Guru Dan Orang Tua Dalam Mendukung Pembelajaran Baca Al-Quran Anak Di Sd It Nurul Ishlah Banda Aceh, 17(2), 194-209.

Saripudin, A. (2017). Strategi pengembangan kecerdasan Naturalis pada Anak Usia Dini. AWLADY: Jurnal Pendidikan Anak, 3(1).

Sutarmanto. (2015). Kompetensi dan Profesionalisme Guru Pendidikan Anak Usia Dini. Jurnal Tabularasa, 5(2), 16-31. https://doi.org/10.1007/sl

Undang-Undang Republik Indonesia Nomor 20 Tahun 2003 Tentang Sistem Pendidikan Nasional (2003).

Yusniar. (2015). Pengelolaan Pembelajaran Melalui Bermain Pasir dan Air Pada Sentra Bahan Alam di PAUD Insan Kamil Bangkinang Kampar. Journal PG-PAUD STKIP Pahlawan Tuanku Tambusari, 1(2). 